\title{
ENSAIO SOBRE A CEGUEIRA: UMA LEITURA SOB A PERSPECTIVA DO
}

MARXISMO

Alexandre da Silva Zanella

\section{RESUMO}

Este estudo volta-se para a análise de como a teoria marxista da sociologia fornece conceitos que permitem uma leitura específica da obra literária Ensaio sobre a cegueira (1995), do escritor português José Saramago. Para tanto, faz-se, primeiramente, uma breve discussão acerca da articulação entre Literatura e Sociedade calcada em Candido (2008), visando mostrar como os condicionamentos sócio-históricos influem na produção literária, já que o elemento externo (social) desempenha um papel importante na constituição da obra, e como ocorre, pois, um deslizamento do estudo da obra em si para a sociedade. Na sequência, são feitos alguns apontamentos acerca dos pressupostos teóricos de Marx (1987) e Marx e Engels (1984), revolvendo principalmente em torno da noção de "materialismo histórico" e trazendo uma breve discussão acerca da organização da sociedade civil em classes. Por fim, procede-se a uma análise sobretudo temática da obra de José Saramago, a partir de alguns recortes levantados, buscando verificar como se dá a articulação entre Literatura e Sociedade na obra selecionada para estudo.

Palavras-chave: literatura; sociedade; marxismo.

\section{BLINDNESS: A READING FROM THE PERSPECTIVE OF MARXISM}

\begin{abstract}
This study aims at analyzing how the sociological Marxist theory provides concepts that allow a specific reading of the literary work Ensaio sobre a cegueira [Blindness] (1995), from Portuguese author José Saramago. Therefore, we make, a priori, a brief discussion about the link between Literature and Society according to Candido (2008), aiming to show how the social and historical elements affect the literary production, since the external element (the social one) plays an important role in the composition of the work, and whereas there is a switch from the study of the work itself to society. In the following, a few notes are made on the theoretical assumption of Marx (1987) and Marx and Engels (1984), mainly revolving around the "Historical materialism" notion and bringing a brief discussion about the organization of the civil society into classes. Finally, we proceed to an essentially thematic analysis of José Saramago's work, from a few excerpts, trying to verify how the relationship between Literature and Society is handled in the selected work for study.
\end{abstract}

Keywords: literature, society, marxism 


\section{Considerações Iniciais}

Tendo em vista a Literatura e mais especificamente a obra literária como fonte de estudo, este trabalho ${ }^{1}$ visa fazer algumas reflexões de viés sociológico acerca da temática abordada no romance Ensaio sobre a cegueira, de autoria de José de Sousa Saramago (19222010), publicada primeiramente em 1995.

A intenção de se trabalhar com esta obra se deu principalmente pelo fato de ela abarcar um entorno social ímpar que permite uma leitura sob um enfoque que se utiliza de alguns escritos de Karl Marx (e também Engels).

Vale apontar, de início, que o estudo da Literatura pode se dar de diversas maneiras e que o que se busca, aqui, é traçar uma linha de estudo que traga algumas considerações e possa atender a algumas necessidades quando do trabalho com esta disciplina e a das Ciências Sociais.

Na sequência, portanto, os intentos serão: a) discutir a relação entre a Literatura e a Sociedade, buscando verificar principalmente como ocorre o "deslizamento" do estudo da obra literária para a sociedade; b) situar a teoria do marxismo, discutindo alguns conceitos primaciais; e c) trazer alguns dados do contexto de produção de Ensaio sobre a cegueira e analisar a temática da obra.

\section{Literatura e Sociedade: uma linha tênue}

O atual estudo da Literatura é resultado de um processo de avaliação e reavaliação das teorias que se ocupavam em estudar as obras literárias, dentre elas a teoria sociológica. Candido (2008) aponta que, historicamente, passou-se de um estudo (da relação obracondicionamento social) que tinha por essência da obra literária a expressão (ou não) de certos aspectos da realidade, os quais "regulavam" o valor e o significado da obra artística, para um estudo que focava a forma como elemento mais importante, relegando o conteúdo a um segundo plano e com ele a dimensão social da obra.

A reavaliação, pois, destes posicionamentos extremos do estudo da Literatura fez com se chegasse ao ponto que hoje é manifesto: não se pende a nenhum destes polos para que não se perca a integridade da obra literária, haja vista que é pela associação do texto (do

\footnotetext{
1 Apresentado como atividade avaliativa parcial da disciplina de Teorias Sociológicas (módulo I), sob a orientação do Professor Pós-Dr. Wander Amaral Camargo.
} 
“interior") e do contexto (do "exterior"), tanto no sentido scricto quanto no lato, que é possível fazer uma interpretação mais íntegra. Além disso, Candido (idem) comenta que hoje se sabe que "o externo (no caso, o social) importa, não como causa, nem como significado, mas como elemento que desempenha um certo papel na constituição da estrutura, tornando-se, portanto, interno" (p. 14, grifos do autor). Em outras palavras, isto significa que o elemento social interfere na coerência da obra tanto quanto outros elementos (psicológicos, linguísticos, etc.) e que, portanto, a obra assimila, dentre todas as dimensões que a compõem, a social como uma delas, sendo um dos "fatores de arte" (ibidem, p. 17).

Portanto, o estudo sociológico da Literatura implica numa união de dois terrenos, o da crítica literária e o da sociologia, que aliam a interdependência entre a estrutura interna e a investigação dos condicionamentos (como, por exemplo, as inclinações sociais dos autores, a influência do meio sócio-econômico e político) que fundamentam a obra e que, por conseguinte, regulam seu significado. Desta forma, percebe-se que para o estudo da obra literária agrega-se a organização interna da obra aos elementos sociais que estão ao seu entorno, também constituintes de sua construção e função sociais. Candido (idem), porém, alerta que se deve levar em consideração a "relação arbitrária e deformante que o trabalho artístico estabelece com a realidade" (p. 22), a fim de não se correr o risco da "simplificação causal" de apenas relacionar a obra à realidade exterior como se esta correlação fosse completa no sentido de buscar um entendimento da obra.

Candido (idem) desenvolve ainda uma questão acerca da influência exercida pela dimensão social sobre a obra artística e, ao mesmo tempo, a influência exercida pela obra de arte sobre essa dimensão, e busca avaliar a relevância deste fator para o estudo da Literatura. $\mathrm{Na}$ verdade, o autor propõe a esta questão duas respostas: a primeira está relacionada ao estudo da arte a fim de verificar em que proporção é expressão da sociedade, e a segunda está relacionada a averiguar em que proporção a arte é, em si, social, isto é, engajada nos problemas sociais. Mais uma vez, o autor aponta que a superação desta dualidade é algo recente, haja vista que os sociólogos entendem hoje que a arte abarca os dois sentidos postos acima; ou seja, a arte depende dos fatores sociais para expressar-se ao mesmo tempo em que é, em si, social, em que tem um "efeito prático" sobre os indivíduos, ora fazendo com eles se identifiquem com a forma de expressão da obra literária, isto é, com os símbolos que o autor lança mão, os quais já são vigentes socialmente ("arte de agregação"), ora o autor renovando este sistema simbólico, com uma nova forma de expressão que se destina primeiramente a 
indivíduos destacados da sociedade ("arte de segregação"). A respeito desses aspectos, resume Candido (2008) que

\begin{abstract}
A integração é o conjunto de fatores que tendem a acentuar no indivíduo ou no grupo a participação nos valores comuns da sociedade. A diferenciação, ao contrário, é o conjunto dos que tendem a acentuar as peculiaridades, as diferenças existentes entre uns e outros. São processos complementares, de que depende a socialização do homem; a arte, igualmente, só pode sobreviver equilibrando, à sua maneira, as duas tendências referidas (p. 33).
\end{abstract}

A partir destes fatores, chega-se à denominada "tríade indissolúvel" de Candido (idem): autor, obra e público. Haja vista que o artista enquanto indivíduo produtor é necessário à criação da obra de arte (literária), ele se destaca por concentrar um conjunto de valores e forças sociais que de alguma forma são os mesmos de um grupo social (muito embora utilize a arte também em virtude de suas aspirações individuais), isto é, reflexos de seu tempo, dando à sua arte, por conseguinte, um caráter de arte coletiva. De certa forma, o autor assume uma função que é a de "ajustar" à sua criação o mundo circundante.

A respeito da obra, não se tratarão aqui dos aspectos de sua configuração, como as relações entre forma e conteúdo que já foram citadas acima. Todavia, vale dizer que a obra nasce da confluência entre a iniciativa individual (do autor) e as condições sociais, e que a(s) ideologia(s) que atravessam a obra estão mais voltadas ao conteúdo, se se fosse fazer uma dissociação entre este e a forma (CANDIDO, 2008).

O último elemento da tríade, o público, é o receptor da obra de arte. Deste, vale dizer que seu agrupamento se dá de maneira informe, de acordo com o momento e com o meio social, do qual podem se desprender grupos que se configurem de maneira distinta do agrupamento maior. É a partir do público que se verificam, por exemplo, as ambições sociais e os valores e ideias que lhe aprazem (CANDIDO, 2008).

A conclusão à qual se quer chegar é a de que o meio social sempre acaba por influenciar na criação artística, seja ela qual for, mas em especial, e o que compete aqui, na literatura. Por conseguinte, o estudo da obra literária está imbricado com o estudo da sociedade, num jogo de mútua troca. 


\section{Alguns Apontamentos Teóricos}

Facina (2004) escreve que, em relação ao estudo de Literatura, deve-se a priori "historicizar" o objeto estudado, isto é, a obra literária. Isso porque os autores são indivíduos integrantes de uma dada época e de uma dada sociedade, e estão submetidos a alguns condicionamentos, tais como classe, etnia, gênero e processo histórico, fatores que de alguma maneira lhes (de)limitam a criação artística (ibidem, p. 9-10). Daí a autora apontar que há uma necessidade de dessacralização a respeito do estudo do processo criativo na Literatura. Tal apontamento fundamenta-se tendo em vista que, durante muito tempo, a Literatura (e, na verdade, a Arte em geral) foi vista sob uma perspectiva platônica de fundo idealista, portanto vista como algo alheio às "condições materiais de produção", isto é, grosso modo, não situada social e historicamente. Historicizar a obra literária seria, então, fazê-la pertencer ao entorno social, inseri-la num movimento histórico, e verificar como a obra reflete (ao mesmo tempo em que refrata) uma realidade.

Ora, seguindo nesse viés, verifica-se que Facina (2004) lança mão de alguns conceitos que se hoje são amplamente conhecidos e divulgados, devem-se fundamentalmente a um autor: Karl Marx ${ }^{2}$.

Das muitas contribuições do filósofo alemão ao campo da Sociologia, destacam-se a seguir algumas de suas noções principais, trazidas em diferentes textos, tendo em vista o que se objetiva com este trabalho.

Marx (1987), em seu Prefácio de Para a Crítica da Economia Política, escreve que seu primeiro trabalho no sentido de elaborar sua teoria foi uma revisão crítica da filosofia de Hegel, estudo a partir do qual chegou à conclusão de que "as relações jurídicas, tais como as formas de Estado", não podiam ser "compreendidas a partir do desenvolvimento geral do espírito humano" (idem, p. 29). Ao contrário, para ele estas relações jurídicas estavam fincadas nas condições materiais de vida, ao inferir que

na produção social da própria vida, os homens contraem relações determinadas, necessárias e independentes de sua vontade, relações de produção estas que correspondem a uma etapa determinada de desenvolvimento das suas forças produtivas materiais. A totalidade destas relações de produção forma a estrutura econômica da sociedade, a base real sobre a qual se levanta uma superestrutura jurídica e política, e à qual correspondem formas sociais determinadas de consciência (p. 29-30, grifos meus).

\footnotetext{
${ }^{2}$ Faz-se a afirmação com o intuito de fincar alguns limites autorais. Não obstante, entendemos que a teoria de Marx é também parte de um processo histórico de levantamentos filosóficos, econômicos e políticos que foram por ele desenvolvidos e que, portanto, não foi pelo filósofo alemão "descoberta" ou "idealizada".
} 
A partir desta perspectiva, Marx (1987) expõe que é o modo de produção material, necessário e independente da vontade dos indivíduos, que regula a vida social, política e espiritual, e não mais a consciência dos indivíduos que a determina. Não obstante,

Em uma certa etapa de seu desenvolvimento, as forças produtivas materiais da sociedade entram em contradição com as relações de produção existentes ou, o que nada mais é do que a sua expressão jurídica, com as relações de propriedade dentro das quais aquelas até então se tinham movido. De formas de desenvolvimento das forças produtivas estas relações se transformam em seus grilhões. Sobrevém então uma época de revolução social. Com a transformação da base econômica, toda a enorme superestrutura se transtorna com maior ou menor rapidez. Na consideração de tais transformações é necessário distinguir sempre entre a transformação material das condições econômicas de produção [...], e [...] as formas ideológicas pelas quais os homens tomam consciência deste conflito e o conduzem até o fim (MARX, 1987, p. 30).

Veja-se que o que Marx faz, na verdade, é propor uma "dialética ${ }^{3}$ materialista", historicamente baseada, processo o qual é o inverso da dialética idealista ${ }^{4}$ de Hegel. Ora, dado que o conflito emerge a partir da contradição entre as forças de produção materiais e as relações de propriedade existentes até então, ou seja, entre "infraestrutura" e "superestrutura", não se pode propor que a revolução/transformação se dê a partir de uma consciência. Ao contrário, conforme propõe Marx (1987), deve-se explicar a transformação a partir de uma base material, isto é, a partir do próprio conflito gerado pela contradição entre as "forças produtivas" e as "relações de produção".

Para o filósofo alemão, o modo de produção burguês é a "última forma antagônica do processo social de produção" (ibidem, p. 30) precedido imediatamente pelo modo de produção feudal. Este antagonismo brota das condições sociais dos homens; não obstante, no próprio interior da sociedade burguesa se encontra a solução para o antagonismo, pois é esta mesma formação social que cria as condições materiais dos indivíduos.

Até aqui, espera-se que tenha sido possível divisar, ainda que grosso modo, o que Marx propôs com seu "materialismo histórico dialético": que o modo de vida dos indivíduos está condicionado pelas suas relações de produção, as quais, entrando em conflito com as

\footnotetext{
${ }^{3} \mathrm{Na}$ esteira de Chauí (2003, p. 43), entenda-se dialética pela "história como processo temporal movido internamente pelas divisões ou negações (contradição)". O termo é de difícil compreensão, mas julgamos esta sintética definição, por ora, suficiente ao objetivo proposto.

${ }^{4}$ Conforme Chaú $(2003$, p. 22): "O idealista [...] considera que o real são idéias ou representações e que o conhecimento da realidade se reduz ao exame dos dados e das operações de nossa consciência ou do intelecto como atividade produtora de idéias que dão sentido ao real e o fazem existir para nós".
} 
relações jurídicas existentes, conduzem a uma relação de dominação de uma classe social sobre outra, e por conseguinte culminam numa necessidade de transformação social que, a partir das bases reais de produção, se opera também na consciência desenvolvida dos dominados acerca dos conflitos entre as classes sociais. Deste modo, é possível afirmar que o "pensamento" é, para Marx, espelho do material/real, pois este é transposto ao cérebro dos indivíduos, e não o contrário.

Ampliemos essas afirmações. Pensando propriamente na produção, em sua Introdução à Crítica da Economia Política, Marx (1987) escreve que o indivíduo do século XVIII é resultado da transformação do modo de vida feudal da sociedade e das novas formas de produção que vinham ganhando cada vez mais espaço. Sendo assim, o autor expõe que o homem de até então estava mais dependente a um conjunto social que era extenso ${ }^{5}$; apenas com a ascensão da burguesia, no período acima delimitado, é que estes conjuntos sociais transformaram-se então num meio de realização de "fins privados", e é à produção deste estágio do desenvolvimento social da sociedade que Marx se volta e ao qual tece suas críticas. Em A Ideologia Alemã , o autor escreve que os meios de vida dos indivíduos submetem-se aos meios de vida existentes, isto é, já determinados socialmente, independentes de sua vontade. Portanto, aquilo que os indivíduos são depende, por consequência, de sua forma de produção (MARX \& ENGELS, 1984).

De fato, partindo desta concepção materialista, Marx e Engels (1984) apontam que "A estrutura social e o Estado decorrem constantemente do processo de vida de determinados indivíduos; [...] como agem, como produzem materialmente, como trabalham, portanto, em determinados limites, premissas e condições materiais que não dependem da sua vontade" ( $p$. 21). A partir desse ponto, o filósofo alemão manifesta que a produção das ideias, as representações, enfim, a consciência dos indivíduos está vinculada às condições materiais regentes, como escreve:

Os homens são os produtores das suas representações, ideias, etc., mas os homens reais, os homens que realizam [...], tais como se encontram condicionados por um determinado desenvolvimento das suas forças produtivas e do intercâmbio que a estas corresponde até às suas formações mais avançadas. A consciência nunca pode ser outra coisa senão o ser consciente, e o ser dos homens é o seu processo real de vida (ibidem, p. 22, grifos meus)

Neste momento, Marx e Engels (1984) asseveram a sua concepção materialista e histórica, na qual não se parte do pensamento, das ideias, e, conforme exemplifica, dos

${ }^{5}$ Marx chama a estes conjuntos "familiares" ou "tribais".

INTRATEXTOS, Rio de Janeiro, 3(1): 44-64, 2011 
homens "fictícios" para depois se chegar aos homens "reais"; ao contrário, o que propõe é que se parta dos indivíduos reais, ativos, e considerando suas condições de produção material para, a partir deles, chegar-se aos "ecos ideológicos” decorrentes do seu processo de vida.

Dos aspectos básicos da atividade social, destaque-se que Marx e Engels (1984) vislumbram o modo de produção vinculado sempre com uma forma de cooperação, a qual é uma força produtiva. Destas forças produtivas disponíveis aos indivíduos condiciona-se a sociedade, o que conecta, por sua vez, a "história da humanidade" à "história da indústria e da troca", novamente afiançando a base condicionada pelos modos de produção material.

Por meios dessas proposições, Marx e Engels (1984) chegam à noção de que os indivíduos fazem sua história porque têm de produzir seus meios de vida, e que isto é dado também por sua "consciência”, porém não (só) por sua consciência natural, mas pela "consciência da necessidade [...] de entrar em ligação com os indivíduos à sua volta" (p. 34), ponto no qual o autor cita estar o início da percepção de que o homem vive em sociedade. Tal percepção, porém, mostra-se inicialmente rudimentar; é a partir da produção e do desenvolvimento da produção (materialidade) que se aprimora esta consciência e, por conseguinte, desenvolve-se a divisão do trabalho. Daí resulta que

\begin{abstract}
estes três momentos, a força de produção, o estado da sociedade e a consciência, podem e têm de cair em contradição entre si, porque com a divisão do trabalho está dada [...] a realidade de a atividade espiritual e a atividade material (atividade e pensamento, isto é, atividade destituída de pensamento e pensamento inativo), o prazer e o trabalho, a produção e o consumo caberem a indivíduos diferentes; e a possibilidade de não caírem em contradição reside apenas na superação da divisão do trabalho (MARX \& ENGELS, 1984, p. 36).
\end{abstract}

Ainda que a consciência vincule-se às condições materiais de produção e às forças produtivas, e que as ideias tenham sua origem na atividade material, Chaui (2003) alerta que

Isso não significa, porém, que os homens representem nessas ideias a realidade de suas condições materiais, mas, ao contrário, representam o modo como essa realidade lhes aparece na experiência imediata. Por esse motivo, as ideias tendem a ser uma representação invertida do processo real, colocando como origem ou como causa aquilo que é efeito ou consequiência, e vice-versa (pp. 60-61, grifo da autora).

A estabilização das ideias e da realidade, alimentadas pela divisão social do trabalho, reafirmam e definem as atividades dos indivíduos. Daí eles ocuparem posições sociais que lhes são impostas, haja vista que as relações sociais surgem-lhes nas ideias como se fossem uma coisa que lhes domina, um poder ao qual não se escapa, quando de fato essas definições são determinadas pela atividade material humana. Há, por conseguinte, uma alienação das 
condições de produção, pois as ideias aparecem anteriores à prática, isto é, àquilo que as definiu. Chaui (idem) escreve também que devido à alienação, enquanto manifestação inicial da consciência em contraposição à práxis, é que a ideologia ${ }^{6}$ é possível. Seguindo ainda o mesmo viés da autora, esta comenta que

As idéias podem parecer estar em contradição com as relações sociais existentes, com o mundo material dado, porém essa contradição não se estabelece realmente entre as idéias e o mundo, mas é uma conseqüência do fato de que o mundo social é contraditório. Porém, como as contradições reais permanecem ocultas (são as contradições entre as relações de produção ou as forças produtivas e as relações sociais), parece que a contradição real é aquela entre as idéias e o mundo (p. 63).

Em relação à dominação de uma classe sobre outra, que surge dos antagonismos gerados pela existência da propriedade privada, isto é, do interesse particular versus o interesse comum, Marx (1984) escreve que as classes que ambicionam o domínio precisam, por sua vez, transpor os domínios anteriores e conquistarem o poder político, haja vista que este poder subjuga o indivíduo via divisão do trabalho, como uma "força alheia".

Por sua vez, o Estado que, em aparência, seria o regulador da realização do interesse comum, na realidade reflete os anseios da classe dominante - burguesa - tomando estes anseios como os gerais. Afinal, o Estado não é um poder distinto da sociedade; é, sim, a parte da sociedade que preserva os interesses particulares da classe dominante e expõe politicamente os ocorridos no âmbito econômico, embora isto não se escancare haja vista que se lança mão de instrumentos de dominação, como as leis, por exemplo, para simular uma espécie de impessoalidade (cf. CHAUI, 2003). Desta forma, conclui-se, sempre com Chaui (idem), que

O Estado é uma comunidade ilusória. Isto não quer dizer que seja falso, mas sim que ele aparece como comunidade porque é assim percebido pelos sujeitos sociais. Estes precisam dessa figura unificada e unificadora para conseguirem tolerar a existência das divisões sociais, escondendo que tais divisões permanecem através do Estado. $\mathrm{O}$ Estado é a expressão política da sociedade civil enquanto dividida em classes. Não é, como imaginava Hegel, a superação das contradições, mas a vitória de uma parte da sociedade sobre as outras (CHAUI, 2003, p. 66).

Levando em consideração que são as relações sociais de produção e sua ideologia que promovem a divisão do trabalho, a sociedade civil (burguesa), definida pelas formas de

\footnotetext{
${ }^{6}$ Definida por ela como "sistema ordenado de ideias ou representações e das normas e regras como algo separado e independente das condições materiais, visto que seus produtores - os teóricos, os ideólogos, os intelectuais - não estão diretamente vinculados à produção material das condições de existência" (CHAUI, 2003, p. 62).
} 
produção e pelas instituições que "mantêm" a sua ideologia, é formada pelas contradições (lutas) entre as classes (dominantes versus dominados) (cf. CHAUI, 2003; MARX \& ENGELS, 1984).

Sobre a questão da luta de classes, vale recuperar a seguinte definição, longa porém esclarecedora, de Chaui (2003):

\begin{abstract}
A luta de classes não é apenas o confronto armado das classes, mas está presente em todos os procedimentos institucionais, político, policiais, legais, ilegais de que a classe dominante lança mão para manter sua dominação, indo desde o modo de organizar o processo de trabalho (separando os trabalhadores uns dos outros e separando a esfera de decisão e de controle do trabalho da esfera de execução, deixando esta última para os trabalhadores) e o modo de se apropriar dos produtos (pela exploração da mais-valia e pela exclusão dos trabalhadores do usufruto dos bens que produziram), até as normas do Direito e o funcionamento do Estado. Ela está presente também em todas as ações dos trabalhadores da cidade e do campo para diminuir a dominação e a exploração, indo desde a luta pela diminuição da jornada de trabalho, o aumento de salários, as greves, a criação de sindicatos livres até a formação de movimentos políticos para derrubar a classe dominante. A luta de classes é o quotidiano da sociedade civil. Está na política salarial, sanitária e educacional, está na propaganda e no consumo, está nas greves e nas eleições, está nas relações entre pais e filhos, professores e estudantes, policiais e povo, juízes e réus, patrões e empregados (pp. 70-71).
\end{abstract}

Sendo assim, a sociedade "faz sua história" por meio da luta das classes, classes estas que não são acabadas, mas em constante formação. Marx e Engels (apud CHAUI, 2003) apontam que os indivíduos têm a impressão de que as classes em que se inserem estão já delimitadas, na ação e no pensamento, como que aguardando pela sua resignação; é, pois, uma relação alienada. Consequentemente, os indivíduos não notam que por meio da práxis social é possível gerar também o movimento da sociedade, isto é, um "movimento real”, que baseado materialmente permitiria a superação deste "estado de coisas" antagônico. Tal movimento que supera o estado de coisas seria a premissa do comunismo para Marx e Engels (1984).

Retornando, enfim, à perspectiva de Facina (2004) do início desta seção, estudar a obra literária é, portanto, considerar o seu autor e o seu público receptor médio como indivíduos que são produtos de um processo histórico de produção material, inseridos numa sociedade dividida em classes. Tais fatores interferem na produção - tanto na constituição da forma, quanto (especialmente) na constituição do conteúdo - e na recepção da obra, haja vista que há um poder ideológico que delimita aspectos do trabalho artístico, muito embora este tenha por característica primacial permitir um exercício de reflexão por meio da contestação do meio social. Nessa perspectiva, estudar a obra literária é também considerar a própria obra 
tocada pelo momento histórico e social em que está inserida, unificador da criação literária e dos sujeitos sociais.

\section{Uma Leitura do Ensaio}

Em se tratando da obra de arte literária, pode-se, em geral, propor duas formas de abordagem do objeto com enfoques distintos: uma levando em consideração principalmente o contexto de produção da obra, contemplando a inserção do autor e da obra num entorno sóciohistórico regulador dessa produção, bem como a inserção do público receptor médio num meio social específico; e outra considerando mormente a temática da obra literária como representação, isto é, a obra permitindo estudar de que forma se desenvolve um determinado tema, reflexão engendrada no interior da própria obra. Saliente-se, todavia, que nenhum destes tipos de estudos exclui a outra parte - ou o interior, ou o exterior da obra; é uma questão didática para o estudo da obra literária (cf. FACINA (2004); CANDIDO (2008)).

Embora se saiba da complexidade de se trabalhar em qualquer dos vieses, o que se busca a seguir é, principalmente, trazer algumas reflexões tomando a obra literária como fonte de desenvolvimento de uma temática, articulando o objeto de estudo com a teoria sociológica elencada acima.

\subsection{Breves considerações sobre o autor ${ }^{7}$}

José de Sousa Saramago nasceu em 1922, em Azinhaga, província do Ribatejo, Portugal (MOISÉS, 2006) e faleceu a 18 de junho de 2010, na ilha de Lanzarote. Em 1998, ganhou o Prêmio Nobel em Literatura.

Ao longo de sua vida, José Saramago atuou como serralheiro mecânico dos Hospitais Civis de Lisboa, funcionário público, tradutor e jornalista ${ }^{8}$. Por volta de meados dos anos de 1970, demitido do periódico Diário de Notícias, mesma época em que se findou a ditadura salazarista em Portugal, à qual o escritor era contrário (ABDALA JR., PASCHOALIN, 1985), decidiu dedicar-se exclusivamente à Literatura, como tradutor e escritor. Entretanto, note-se que o primeiro romance do escritor do Ribatejo, Terra do pecado, data de 1947, e que, em

\footnotetext{
${ }^{7}$ Esta subseção apresenta uma versão adaptada de um capítulo da monografia de minha autoria, intitulada Ensaio sobre a cegueira e Cem anos de solidão: perspectivas de leitura, cuja defesa ocorreu em novembro/2009.

${ }^{8}$ Informações disponíveis em <http://www.josesaramago.org/site/Cronobiografia.aspx>. Acesso em 29/06/2009.
} 
1966, já se havia lançado Os poemas possíveis, marcando um início, ainda que moderado, de sua carreira literária ainda antes da década de 1970.

Porém, foi de fato nos anos 70, com sua dedicação exclusiva à Literatura, que o autor passou a publicar maior número de obras, tais como: O Ano de 1993 (poesia, 1975), Objecto quase (contos, 1978), A noite (peça teatral, 1979), e finalmente, já em 1980, o romance Levantado do chão, que marca uma nova fase da carreira artística do autor português, quando se assinala o "estilo saramaguiano"9 que permeará toda a sua publicação em prosa até o fim de sua vida.

Pode-se, deste modo, dividir a carreira literária de Saramago em duas fases: a primeira, na qual se têm a lírica, o teatro, a crônica, o conto e raros romances, e a segunda, considerada pela crítica literária mais aprimorada, em que se publicaram seus romances mais conhecidos e, também, polêmicos - dentre eles, destacam-se Memorial do Convento (1982), O Evangelho segundo Jesus Cristo (1991) e Ensaio sobre a cegueira (1995) -, por demonstrarem um lado mais engajado do autor ${ }^{10}$, cujas convicções não agradavam de todo as instituições sociais dominantes. O que não se pode passar por cima, pois, é o trato de questões sociológicas interligado com alta elaboração estético-formal que permeia todas as fases do autor.

Poder-se-ia afirmar que a Literatura saramaguiana é "insistente", se se quisesse resumi-la em um termo. No caso de observar a vida de José Saramago, veem-se alguns porquês: além do já exposto, o autor foi ativista explícito, e esteve ligado, por exemplo, ao movimento zapatista, mais especificamente, e a movimentos anti-ditatoriais em geral, além de manifestações mundiais a favor da paz e contra o terrorismo. Ainda, foi declaradamente ateu e comunista (CASTRO, 2007).

Quanto às temáticas que explora, Saramago lança mão de assuntos controversos, tais como epidemias, clonagem, e acidentes geográficos, tratados por cunho contestador,

\footnotetext{
${ }^{9}$ Refere-se, neste momento, à composição estilística. A construção ficcional de Saramago é de fato inovadora: quanto à forma estrutural de seus escritos, há parágrafos que podem durar várias páginas, períodos que podem durar várias linhas, aproximação do discurso oral por meio da escrita, e algumas interferências do narrador a seu bel-prazer, para citar apenas alguns exemplos.

${ }^{10}$ Entenda-se "engajado" diferentemente de "tendencioso". Sobre esta questão, vale recuperar a seguinte fala de Saramago: "Eu refuto a literatura de partido, coisa que, aliás, parece que se pode deduzir facilmente daquilo que fiz até hoje. O que eu não refuto é isto: se eu estou ideologicamente determinado ou caracterizado de uma certa maneira, se sou uma pessoa cujo mundo está organizado também em função de um certo entendimento da História ou da sociedade ou do funcionamento das forças sociais, então eu creio que, mesmo que eu não esteja a dizer naquilo que escrevo «Viva o Partido!», é facílimo ao leitor atento entender que o autor que ele está a ler pensa de uma maneira determinada." (REIS, 1998, p. 75 apud LACERDA \& PEREIRA, 2008, sem indicação de página).
} 
subversivo, desmitificador, e também de caráter histórico. A confluência destes fatores concebe uma Literatura tanto artística quanto engajada.

\subsection{A obra sob o olhar do marxismo: uma leitura possivel?}

Ensaio sobre a cegueira (1995) é hoje um dos livros de José Saramago mais conhecidos mundialmente, traduzido para mais de quinze idiomas e que conta com uma produção cinematográfica ${ }^{11}$. Nesta obra literária, o autor desvincula-se das personagens históricas usualmente empregadas até então para inserir personagens sem nome próprio; situa sua diegese (história) numa cidade grande mas sem referência a qualquer lugar existente, real, o que nos permite configurar a imagem de qualquer cidade ocidental-capitalista; lança mão de símbolos, como o da cegueira, para expor a sociedade contemporânea e suas incertezas, medos, contradições, etc.; além de outras questões de igual relevância, como a inquietação que o autor parece demonstrar sobre alguns pré-conceitos enraizados no modo de vida desta atual sociedade. Agregue-se a estes fatores o veio irônico constantemente empregado na narrativa saramaguiana, elemento que consagra o tom subversivo que permeia a obra do autor português.

Ora, tomando por ponto de partida a trajetória de vida de Saramago supracitada e o momento de publicação da obra, é possível delimitar o meio sócio-econômico no qual o autor estava inserido: a sociedade ocidental-capitalista em fins do século $\mathrm{XX}$, próximo à virada do milênio, lidando com o aparecimento/crescimento da Internet e com a ideia de um mundo globalizado. Aceitando estes condicionamentos sociais, pode-se buscar em Ensaio sobre a cegueira (1995) como, de um lado, eles atuam no momento de produção da obra e, por outro, como estão presentes na própria obra.

Pode-se dizer que, pelo fato de José Saramago ser declaradamente comunista, esta inclinação, por si só, já conflui para algumas considerações acerca de sua obra. O fato de o autor causar uma revolução pela linguagem já é um recurso de análise. Não raro ouve-se dizer que a leitura de seus livros é "difícil", porque não se vale de pontuação e divisão de parágrafos canônicos. Ora, numa sociedade em que prevalece a velocidade, a escrita, como parte deste domínio, também evolui à medida que avançam os meios digitais de comunicação,

\footnotetext{
${ }^{11}$ BLINDNESS. Direção: Fernando Meirelles. Produção: Andrea Barata Ribeiro; Niv Fichman; Sonoko Sakai. Intérpretes: Alice Braga; Danny Glover; Gael García Bernal; Julianne Moore; Mark Ruffalo. Roteiro: Don McKellar; José Saramago (romance). Brasil/Canadá/Japão: O2 Filmes; Rhombus Media; Bee Vine Pictures, 2008. 1DVD (121 min), son., color. - Filme selecionado para a Noite de Abertura do Festival de Cannes 2008.
} 
tais como blogues e sítios de relacionamento interpessoal que limitam o uso de caracteres. $\mathrm{O}$ fato de José Saramago valer-se de uma composição estrutural vai, pois, em sentido inverso nesta sociedade.

Além disso, já no interior textual, os elementos presentes e o veio irônico corroboram seu posicionamento político, como se verifica, por exemplo, no momento em que o homem que ajuda o primeiro cego rouba-lhe em seguida o carro, mas logo cega também, como se lê:

\begin{abstract}
Ao oferecer-se para ajudar o cego, o homem que depois roubou o carro não tinha em mira, nesse momento preciso, qualquer intenção malévola, muito pelo contrário, o que ele fez não foi mais que obedecer àqueles sentimentos de generosidade $\mathrm{e}$ altruísmo que são, como toda a gente sabe, duas das melhores características do género humano, podendo ser encontradas até em criminosos bem mais empedernidos do que este, simples ladrãozeco de automóveis sem esperança de avanço na carreira, explorado pelos verdadeiros donos do negócio, que esses é que se vão aproveitando das necessidades de quem é pobre. No fim das contas, estas ou as outras, não é assim tão grande a diferença entre ajudar um cego para depois o roubar e cuidar de uma velhice caduca e tatebitate com o olho posto na herança (SARAMAGO, 1995, p. 25).
\end{abstract}

Verifica-se, a partir deste trecho, que ao mesmo tempo em que o autor expressa uma sociedade específica na obra (a que é regida pela luta de classes: há o empregado dominado e o empregador dominante), e particularmente um indivíduo desta sociedade (o empregado que, explorado pelos patrões, rouba um carro para ascender socialmente), a própria obra é social à medida que tanto agrega grupos sociais (o da obra e o do leitor - os quais vêm a ser o mesmo grupo), quanto segrega (acentua as diferenças entre os grupos sociais). Daí faz-se a união dos três elementos citados por Candido (2008): o autor, inserido sócio-historicamente, escreve a obra que é também produto deste meio porque reflete e refrata a sociedade, a um grupo receptor cujo meio social é, em geral, o mesmo. A ironia vem no sentido de mostrar a hipocrisia da sociedade burguesa: o ato de roubar de um incapacitado de enxergar, enquanto malvisto na "sociedade capitalista regida por leis que defendem o bem-estar dos cidadãos", não difere daquilo que a mesma burguesia faz quando cuida de um idoso da família (ainda que o coloquem, quando não o esquecem, num asilo) aguardando sua parte da herança. Saramago lança mão destas relações sociais para evidenciar, mais do que apenas mostrar, como as classes dividem-se e se contradizem, porque tece sua crítica do interior desta sociedade ao mesmo tempo voltando-se contra ela.

Pensando mais especificamente na diegese, apresenta-se uma sociedade configurada como capitalista, regida pelas leis deste sistema e, conforme já se disse, dividida em classes. Portanto, tem-se uma regulação da vida social (espiritual e política) de base econômica, cujas 
relações de produção formam uma infraestrutura à qual se sobrepõe relações jurídicas e políticas como uma superestrutura. $\mathrm{Na}$ obra, verifica-se como a sociedade capitalista, distinguindo dominantes e dominados, está subjugada pelo Estado, que figura como mediador do interesse geral.

Um exemplo do que se quer dizer pode ser visto quando, no capítulo terceiro de Ensaio sobre a cegueira (1995), o ministério da saúde é acionado para lidar com os casos de cegueira branca (até então se conhecem os casos do primeiro cego, do médico e do rapazinho estrábico - mas indica-se já a possibilidade de outras ocorrências):

O ministério queria saber a identidade dos pacientes que tinham estado no dia anterior no consultório, o médico respondeu que as fichas clínicas respectivas continham todos os elementos de identificação, o nome, a idade, o estado civil, a profissão, a morada, e terminou declarando-se ao dispor para acompanhar a pessoa ou pessoas que fossem recolhê-los. Do outro lado o tom foi cortante, Não precisamos. O telefone mudou de mão, [...] Boas tardes, fala o ministro, em nome do Governo venho agradecer o seu zelo, estou certo de que graças à prontidão com que agiu vamos poder circunscrever e controlar a situação, entretanto faça-nos o favor de permanecer em casa. As palavras finais foram pronunciadas com expressão formalmente cortês, porém não deixavam qualquer dúvida sobre o facto de serem uma ordem. (SARAMAGO, 1995, p. 42).

O gabinete passa a coletar informações dos cegos e opta por isolá-los num manicômio (sendo esta a única opção restante de um leque maior, que incluía um hipermercado, um quartel e uma feira industrial, esta última nem cogitada a hipótese haja vista que "A indústria não gostaria com certeza [que lhe enviassem os cegos], estão ali investidos milhões" (SARAMAGO, 1995, p. 46)) para evitar uma contaminação maior, visando o "bem-estar" da população. Fá-lo por meio da ordem, da imposição, aceita pelos indivíduos pelo fato de o Estado ilusoriamente os representar a todos, quando o que visa na verdade é a comodidade de uma parcela da população que é a burguesa e que não poderia ser atingida pelo "mal-branco" haja vista que, o sendo, o Estado também seria. No entanto, da cegueira, ninguém exceto a mulher do médico escapa, nem mesmo a classe dominante, muito embora este não seja o fim do problema, como se verá adiante.

Já foi dito anteriormente neste estudo que a divisão do trabalho que resulta na dualidade entre dominantes e dominados define as atividades dos indivíduos. Ora, na obra Ensaio sobre a cegueira, a divisão do trabalho define precisamente os indivíduos. Estes não têm nome próprio, mas identificam-se por suas atividades ou situação: o médico, a mulher do médico, a secretária, o ladrão, o polícia, a empregada. Não obstante, quando todos esses 
indivíduos são postos em quarentena no manicômio, tornam-se todos igualmente cegos de um tipo de cegueira específica, branca, e criam uma nova comunidade - que não vai se construir pacificamente - colocada em posição oposta à do governo. Diz-se da não pacificidade haja vista que, quando colocados no manicômio, os cegos têm de organizarem-se conforme suas novas condições materiais naquele lugar. Não obstante, deixar para trás aquilo que os constituía como sujeitos sociais antes da cegueira é algo que não se dá em marcha rápida. É preciso avançar compassadamente até que se entenda que o meio social em que se vivia era algo fundado a partir das relações econômicas de produção, às quais o indivíduo era alienado.

Vale apontar que, ainda dentro do manicômio, as alas tentam organizar-se como pequenos sistemas políticos; uma proposição que parece indicar um vestígio ideológico instaurado pelo capitalismo de que haveria de ter um tipo de governo (de base capitalista) a atender a todas as necessidades, o que, na verdade, não ocorre, pelo menos não para todos. Pode-se exemplificar este caso com o trecho em que a ala três instaura um poder e passa a regular toda a comida que era destinada aos cerca de 250 cegos que estavam no manicômio:

Está dito e não há volta atrás, a partir de hoje seremos nós a governar a comida, ficam todos avisados, e que ninguém tenha a ideia de ir lá fora buscá-la, vamos pôr guardas nesta entrada, sofrerão as consequências de qualquer tentativa de ir contra as ordens, a comida passa a ser vendida, quem quiser comer, paga [...]. Cada camarata nomeará dois responsáveis, esses ficam encarregados de recolher os valores, todos os valores, seja qual for a sua natureza, dinheiro, joias, anéis, pulseiras, brincos, relógios, o que lá tiverem, e levam tudo para a terceira camarata do lado esquerdo, que é onde nós estamos, e se querem um conselho de amigo, que não lhes passe pela cabeça tentarem enganar-nos, já sabemos que alguns de vocês vão esconder uma parte do que tiverem de valioso, mas digo-lhes que será uma péssima ideia, se não nos parecer suficiente o que entregarem, simplesmente não comem, entretenham-se a mastigar as notas de banco e a trincar os brilhantes (SARAMAGO, 1995, p. 1401).

Daí o conflito entre as camaratas ser uma metáfora para a própria luta de classes. Dependentes da "classe dominante", isto é, da camarata três, que se instaura também como "governo", a "classe" dos sem acesso à comida é dominada pelas novas regras sociais impostas, pelo fato de terem de pagar para poderem comer, pagamento que atinge o mais alto preço: as mulheres da camarata, como ocorre depois, com o fim dos pertences. Não obstante, a partir das mesmas relações sociais surge a necessidade de transformação daquele meio, que atinge seu auge com a morte do "chefe dos malvados" pela mulher do médico, ato que simboliza a libertação daquele sistema. 
Que foi que se passou, perguntou o médico, disseram que foi morto um homem, Sim, matei-o eu, Porquê, Alguém teria de o fazer, e não havia mais ninguém, $\mathrm{E}$ agora, Agora estamos livres, eles sabem o que os espera se quiserem outra vez servir-se de nós, Vai haver luta, guerra, Os cegos estão sempre em guerra, sempre estiveram em guerra, Tornarás a matar, Se tiver de ser, dessa cegueira já não me livrarei, E a comida, Viremos nós buscá-la, duvido que eles se atrevam a vir até aqui, pelo menos nestes próximos dias terão medo de que lhes suceda o mesmo, que uma tesoura lhes atravesse o pescoço, Não soubemos resistir como deveríamos quando eles apareceram com as primeiras exigências, Pois não, tivemos nós medo, e o medo nem sempre é bom conselheiro, e agora vamo-nos, será conveniente, para maior segurança, que barriquemos a porta das camaratas pondo camas sobre camas, como eles fazem, se alguns de nós tivermos de dormir no chão, paciência, antes isso do que morrer de fome. (SARAMAGO, 1995, p. 189-190).

A libertação, nesse caso, baseada na situação real imediata, é também a chave para a libertação das relações sociais capitalistas em sentido amplo, as quais constituíam o sistema político vigente num estágio avançado de desenvolvimento, e ao qual os dominados não tinham acesso algum (representado, na obra, pela metáfora da barricada de camas). Por meio da superação da classe dominante pela classe dominada, baseada nas condições reais dos indivíduos, opera-se uma revolução também na ideologia ${ }^{12}$. Pode-se concluir, portanto, que conforme expôs Marx, não poderia haver a transformação social sem a luta entre as classes. Porém, como se lê no excerto acima, com a revolução eleva-se a necessidade de combater o retorno do sistema político anterior por meio do mesmo sistema. A metáfora que pode exemplificar este ponto é a de quando as mulheres decidem encarar a humilhação de retornar à camarata onde haviam sido estupradas por comida para "libertarem-se dessa humilhação", o que promove uma espécie de "abrir de olhos" geral:

\begin{abstract}
Não irão apenas, os homens, irão também as mulheres, voltaremos ao lugar onde nos humilharam para que da humilhação nada fique, para que possamos libertar-nos dela da mesma maneira que cuspimos o que nos lançaram à boca. [...] $\mathrm{O}$ velho da venda preta sorriu, pareceu um sorriso feliz, e talvez o fosse, [...] mais interessante é reparar na expressão de estranheza dos outros cegos, como se alguma coisa lhes tivesse passado por cima das cabeças, um pássaro, uma nuvem, uma primeira e tímida luz. O médico segurou a mão da mulher, depois perguntou, Ainda há quem esteja aqui a pensar em descobrir quem matou aquele, ou estaremos de acordo em que a mão que o foi degolar era a mão de todos nós, mais exactamente, a mão de cada um de nós. (SARAMAGO, 1995, p. 193).
\end{abstract}

Isso é dito porque os ecos da "ideologia anterior", contudo, não haviam cessado de uma hora para outra, como nem era de se esperar:

\footnotetext{
${ }^{12}$ Em uma de suas notas de Sobre a Literatura e a Arte, retirada do Manifesta do Partido Comunista, Marx e Engels (1971) escrevem justamente que conforme se alteram as condições sociais, alteram-se as concepções ideológicas.
} 
[...] um dos homens disse, $\mathrm{O}$ que eu sei é que não estaríamos nesta situação se não fosse terem-lhe matado o chefe, que importância teria irem lá as mulheres duas vezes por mês a dar-lhes o que deu para dar-se a natureza, pergunto. [...] O que devíamos fazer era tomar a justiça nas nossas mãos e levá-lo ao castigo. (SARAMAGO, 1995, p. 191).

O "capitalista", por assim dizer, ainda que sob condições subumanas no manicômio, estava de tal modo alienado das "relações de produção" que não podia ver naquele ato de revolta uma revolução social que viria a favor de todos, uma "libertação dos grilhões". A sequência narrativa, contudo, mais uma vez mostra como a força dos dominantes (os da terceira camarata) se sobressai, pelo fato de estes estarem armados enquanto os outros não, numa metáfora que se poderia relacionar aos instrumentos de dominação que a classe dominante detém sob seu poder.

A partir do momento de queda do poder no manicômio, na diegese coincide a queda do Estado. Os cegos confinados não se dão conta, porém, deste fato até que a comida que vinha do governo deixa de chegar. Já num momento de inquietação, depois, em que os cegos decidem levar os cadáveres feitos pelos indivíduos da terceira camarata para fora do local, uma mulher toca fogo na pilha de camas que separava a ala três, onde se comia e bebia do que haviam estocado a tirar dos outros cegos. Afora o pânico instaurado, os cegos conseguem sair do prédio em chamas. Aí encontram a guarda vazia e os portões abertos: "a mulher do médico anunciou em altas vozes que estavam livres" (SARAMAGO, 1995, p. 210).

Neste momento em que se amplia a perspectiva em torno da cidade, vê-se que a queda do sistema capitalista como um todo trouxera uma mudança radical, porém destaca-se, mais do que a devastação causada por um "mundo de cegos", a forma como os indivíduos têm de se restabelecerem por meio de condições básicas, primeiro de sobrevivência, depois de organização, e como estes fatores renovam suas formas de perceber o mundo circundante e, enfim, o pensamento.

Somente então, após a experiência de terem cegado, os indivíduos compreendem que, num mundo em que tinha perdido a essência humana em troca da aparência gerada pela desvinculação do homem com suas relações materiais, isto é, pela alienação econômica, para voltarem a enxergar, tinham de resgatar essa essência e reerguer a sociedade de forma organizada e comum a todos:

[...] o médico só disse, Se eu voltar a ter olhos, olharei verdadeiramente os olhos dos outros, como se estivesse a ver-lhes a alma. A alma, perguntou o velho da venda preta, Ou o espírito, o nome pouco importa, foi então que, surpreendentemente, se tivermos em conta que se trata de pessoa que não passou por estudos adiantados, a 
rapariga dos óculos escuros disse, Dentro de nós há uma coisa que não tem nome, essa coisa é o que somos. (SARAMAGO, 1995, p. 262).

Pode-se interpretar que o fator causador da cegueira parece constituir, pois, uma metáfora do excesso de valorização do mundo das coisas que permeia a sociedade atual capitalista e, entretanto, não lhe é transparente. Portanto, somente por meio da cegueira é que os homens podem resgatar o seu "ser", em contraponto ao "aparecer", e enfim "ver" aquilo que lhes é mais interno, fundado a partir de suas relações materiais de vida, e não serem apenas conduzidos por uma ideologia dominante que se lhes sobrepõe sem questionamento porque lhes parece desde sempre dada, como entidade superior; abre-se, assim, o olhar à reflexão. Crê-se que o voltar a enxergar é, por conseguinte, também a superação de um estágio social que, embora se coloque como sendo de todos, não se constitui desta forma realmente. "Ver" assume então o sentido de "ter razão em não acreditar [apenas] na razão", de perceber que a organização pode se dar de maneira distinta à da sociedade de consumo: "o corpo também é um sistema organizado [...]. [...] organizar-se já é, de uma certa maneira, começar a ter olhos [...]” (SARAMAGO, 1995, pp. 281-2). Ao fim, todos se dão conta das transformações que se deram em seus interiores, isto é, a renovação das relações entre os indivíduos e as concepções acerca da vida em comunidade, ou seja, suas revoluções também ideológicas, como é o caso do velho da venda preta que já velho, calvo e meio cego, já não esperava muito da vida, quando a cegueira que ocorre a todos exceto a mulher do médico faz com que ele se reintegre de alguma forma a um grupo social. A cegueira, para este homem, é expressão de um desejo interno, "O monstruoso desejo de que não venhamos a recuperar a vista, Porquê, Para continuarmos a viver assim, Queres dizer, todos juntos, ou tu comigo [a rapariga dos óculos escuros] [...]" (SARAMAGO, 1995, p. 291), ao qual a rapariga lhe responde que, fosse no mundo anterior à cegueira branca, ela certamente não o quereria. Isto porque verifica-se que já não são mais os mesmos valores e crenças que estão presentes na sociedade da cegueira branca. Nesta, embora se tenham limitações de toda sorte, há algo que é fundamental: a recuperação da essência humana, recuperação esta que provavelmente os fará, um a um, recobrar a visão e entender que, mesmo vendo, se está cego: "Por que foi que cegámos, Não sei, talvez um dia se chegue a conhecer a razão, Queres que te diga o que penso, Diz, Penso que não cegámos, penso que estamos cegos, Cegos que veem, Cegos que, vendo, não veem" (SARAMAGO, 1995, p. 310). 


\section{Reflexões Finais}

Longe de fazer uma leitura interpretativa que dê conta da completude da obra, o que se buscou neste estudo foi mostrar como José Saramago lança mão de uma temática que faz parte de seu "engajamento" (reitere-se que o autor foi declaradamente comunista) para demonstrar um entorno social que ao mesmo tempo em que constitui uma representação do mundo real, quer negá-lo. Em Ensaio sobre a cegueira se "constrói” uma sociedade na qual se antecipa, por assim dizer, a decadência de um sistema político-econômico em estágio avançado, posta numa dualidade entre os indivíduos e o poder.

Em outras palavras, em Ensaio sobre a cegueira é possível observar como José Saramago mobiliza o seu momento histórico e a sociedade de sua época a fim de apresentar e questionar artisticamente o mundo contemporâneo; as aspirações mais ou menos individuais do autor manifestam-se em seus posicionamentos, suas convicções, enfim, na ideologia que perpassa a obra.

A teoria sociológica de Marx, embora tenha sido voltada a uma discussão política e econômica, deu bases filosóficas que permitem aplicar noções a outros domínios, como este da Literatura. Por meio da noção do materialismo histórico, por exemplo, pode-se entender que a compreensão da Literatura não é possível complementarmente numa perspectiva da obra como fechada em si mesma, isolada de uma situação sócio-histórica; pelo contrário, é no movimento social e histórico que a Literatura se desenvolve.

Vale citar, ainda, um comentário de Saramago: "O cidadão que o escritor é não pode ocultar-se por trás da obra. Ela, mesmo importante, não pode servir de esconderijo para dar ao autor uma espécie de boa consciência graças à qual ele poderia dizer que está ocupado e não tem tempo para intervir na vida do país"13. Mais uma vez, vê-se aí que o estudo da obra literária está imbricado com o estudo da sociedade, numa coerência bilateral.

Por fim, a partir da análise feita neste estudo, é possível verificar como os escritos de Marx continuam, à luz do século XXI, atuais, à medida que podem ser aplicados a corpora contemporâneos de análise, ainda que hoje se tenha inúmeras releituras de sua teoria.

13 Disponível em: http://caderno.josesaramago.org/2010/07/26/o-cidadao-que-o-escritor-e/. Acesso em 27/07/2010. 


\section{Referências Bibliográficas}

ABDALA JÚNIOR, B.; PASCHOALIN, M. A. História social da literatura portuguesa. São Paulo: Ática, 1985.

CANDIDO, A. Literatura e Sociedade: estudos de Teoria e História Literária. 10. ed. Rio de Janeiro: Ouro sobre Azul, 2008.

CASTRO, R. C. Dossiê José Saramago: a leste do Éden. Revista EntreLivros. São Paulo, Duetto Editorial, ano 2, vol. 23, pp. 24-30, mar./2007.

FACINA, A. A literatura e a pesquisa em ciências sociais. In: Literatura e sociedade. Rio de Janeiro: Jorge Zahar, 2004.

LACERDA, W.; PEREIRA, M. L. S. Literatura e política na ficção de José Saramago. Anais do XI Congresso Internacional da Associação Brasileira de Literatura Comparada. São Paulo, 2008 - Tessituras, Interações, Convergências / Sandra Nitrini et al. e-book.

MARX, K. Manuscritos econômico-filosóficos e outros textos escolhidos. 4. ed. trad. José Carlos Bruni et al. São Paulo: Nova Cultural, 1987.

MARX, K.; ENGELS, F. A ideologia alemã. São Paulo: Moraes, 1984.

. Sobre a Literatura e a Arte. Lisboa: Estampa, 1971.

MOISÉS, M. A literatura portuguesa através dos textos. 30. ed. São Paulo: Cultrix, 2006.

SARAMAGO, J. Ensaio sobre a cegueira. São Paulo: Companhia das Letras, 1995. 